\title{
А.Ю. Лесь
}

\section{СТРАТЕГИЧЕСКИЕ СОЮЗНИКИ РОССИИ НА ГАОБАИЬНОМ МЕАИАПРОСТРАНСТВЕ}

Аннотация. Статья посвящена взаимоотношениям России с ее стратегическими союзниками на мировом информачионном пространстве. В статье приведень примеры взаимодействия стран БРИКС в преодолении информационных угроз и обеспечении глобальной медиабезопасности.

Ключевые слова: стратегические союзники, информационная конфронтация, информационно-коммуникативные технологии (ИКТ), глобальное медиапространство.

Лесь Анастасия Юрьевна - аспирантка кафедры глобалистики факультета глобальных процессов Московского государственного университета имени М.В. Ломоносова.

E-mail: les_nastya@mail.ru

\section{A.Yu. Les. Strategic Allies of Russia on the Global Mediaspace}

Abstract. This article is devoted to Russia's key strategic allies on the Global Mediaspace. The article also illustrates examples of the BRICS factor on the Global Mediaspace.

Keywords: strategic allies, informational confrontation, information and communication technologies (ICT), Global Mediaspace.

Les Anastasia Yuryevna - postgradate student,

Department of globalistics, faculty of Global studies,

Lomonosov Moscow State University.

E-mail: les_nastya@mail.ru

Перефразируя Александра III, заявлявшего, что у России только два союзника - ее армия и флот, можно сказать, что на глобальном медиапространстве у России также два союзника - русский язык и информационные технологии. На их основе возможно осуществление успешной информационной политики на международном уровне. 
Если говорить об институте стратегического союзничества в более традиционном ключе, то основными партнерами России по освоению глобального медиапространства являются страны СНГ, БРИКС и ШОС. В рамках БРИКС (Бразилия, Россия, Индия, Китай, Южно-Африканская Республика) [6, с. 115] и Содружества Независимых Государств (Россия, Белоруссия, Азербайджан, Армения, Узбекистан, Молдова, Казахстан, Таджикистан, Киргизия, а также Украина [5, с. 6], в парламенте которой в настоящее время рассматривается вопрос о выходе из Содружества) осуществляются многочисленные совместные программы, направленные на защиту и продвижение интересов входящих в эти объединения стран. Организацией стратегических союзников также является Шанхайская организация сотрудничества (ШОС), в которую входят Россия, Китай, Казахстан, Узбекистан, Таджикистан, Киргизия.

В последние годы на международной арене неуклонно возрастает уровень информационных угроз, а проблема информационной безопасности становится одной из важнейших детерминант национальных стратегий. Растет значимость международного сотрудничества в этой сфере. Страны-союзницы разрабатывают совместные программы противодействия глобальным информационным вызовам и достижению общих целей развития.

Вопросы информационной политики постоянно рассматриваются странами - участницами СНГ, БРИКС и ШОС в рамках международных конференций и саммитов в течение последних пяти лет. В документах этих форумов отмечается необходимость совершенствования технологий обнаружения возникающих информационных угроз и углубления сотрудничества в области противодействия международному терроризму и экономической киберпреступности на мировом медиапространстве.

Особенно глубоким является сотрудничество России со странами СНГ, оно осуществляется по всем направлениям, в том числе и в сфере информационного развития. Даже смена внешнеполитического курса Украины и обострение в последние годы российско-украинских отношений (в том числе информационная конфронтация) не смогли прервать глубинных связей между нашими странами. Информационный сектор стран Содружества исторически связан с русскоязычным вещанием и технологическим базисом средств массовых коммуникаций. На ежегодных саммитах СНГ, которые проводятся с 1991 г., обсуждаются актуальные вопросы сотрудничества, выдвигаются решения по возникающим угрозам, в том числе и информационным.

Новые перспективы сотрудничества в сфере информационной политики открывает для России взаимодействие в рамках ШОС и особенно БРИКС.

С нарастанием информационных угроз проблема медиабезопасности стала занимать все большее место в документах саммитов БРИКС. 
На VII саммите стран БРИКС, состоявшемся в Уфе 8-9 июля 2015 г., обсуждались перспективы сотрудничества стран-участниц на ближайшее пятилетие. Вопросы информационной политики нашли отражение в ряде итоговых документов. В соглашении о сотрудничестве государств БРИКС до 2020 г. были отмечены меры внешнеполитического, социально-экономического, а также информационного плана. На саммите была подписана Уфимская декларация, в которой среди других важных вопросов (таких, как возможность перехода к торговым обменам в национальной валюте, распространение международного терроризма, кризис в Греции, события на Украине и т.п.) не затерялись и проблемы информационного характера, в частности проблема негативного влияния информационного противоборства на развитие международных отношений [2].

Особое внимание к проблемам информационного сотрудничества было уделено на саммите БРИКС на Гоа 16 октября 2016 г. Более десяти пунктов итоговой декларации саммита посвящены проблемам использования информационно-коммуникационных технологий (ИКТ) на глобальном медиапространстве, что иллюстрирует остроту данного вопроса. Так, в пункте 64 страны-участницы подчеркнули значимость информационного сектора в сохранении вектора устойчивого развития и призвали международное сообщество к разработке всеобъемлющего подхода к определению принципов и стандартов использования ИКТ на международной арене. «Мы вновь подтверждаем, - говорится в Декларации, - что развитие ИКТ является ключевым фактором обеспечения устойчивого развития, международного мира и безопасности, соблюдения прав человека. Мы соглашаемся наращивать совместные усилия в целях повышения безопасности в сфере использования ИКТ, борьбы с применением ИКТ в преступных и террористических целях, а также совершенствования сотрудничества между нашими профильными структурами, занимающимися вопросами технического характера, правоприменения, НИОКР ${ }^{1}$ и инноваций в области ИКТ, наращивания информационного потенциала. Мы заявляем о нашей приверженности сокращению цифрового технологического разрыва между развитыми и развивающимися странами. Мы признаем, что наш подход должен быть многовекторным и инклюзивным, а также содержать углубляющееся понимание проблемы доступа к цифровым технологиям» [3]. Пункт 65 Декларации акцентирует внимание на фундаментальной роли современных информационных технологий в сохранении принципов прав и свобод человека [3].

Странами БРИКС была достигнута договоренность о кооперации в сфере обеспечения безопасности информационно-коммуникационных технологий,

1. Научно-исследовательские и опытно-конструкторские работы. 
а также о совместном противодействии использованию ИКТ в преступных целях. Важная роль отводится обмену опытом в использовании информационно-коммуникационных технологий и совместному мониторингу и контролю мирового рынка программного обеспечения [3].

Страны БРИКС исторически и цивилизационно далеки друг от друга, что затрудняет, но не нивелирует возможность сохранять их стратегическое партнерство. Рассматривая вектор дальнейшего взаимодействия стран БРИКС, специалисты отмечают необходимость развития диалогового формата в решении ключевых вопросов. Именно диалог позволит странам БРИКС сохранить «способность согласовывать интересы и действия на международной арене» [1, с. 52]. В полной мере это относится и к сотрудничеству в сфере информационной политики. Современные информационно-коммуникативные технологии позволяют эффективно осуществлять совместные проекты практически независимо от географии и цивилизационных истоков участников международного взаимодействия.

В современном мире в основе стратегического союзничества лежит не столько географическая и историческая близость, сколько совпадение интересов стран - участниц объединений и партнерств. У стран БРИКС эти интересы совпадают во многих аспектах, в том числе в вопросах противодействия информационному терроризму, обеспечения информационной безопасности, а также в купировании процесса дезинформации населения через средства массовой коммуникации, получившего в конце 2016 г. характер глобальной эпидемии [10, с. 67].

Таким образом, для достижения эффективного результата международного сотрудничества следует учитывать особенности каждой страны - участницы группы и придерживаться совместно разработанных принципов информационной политики.

Нарастание информационных угроз сопровождается углублением информационной конфронтации на международной арене. Особенно острым характером отличается медийное противостояние между Россией и Западом, наметившееся во время украинского кризиса 2014 г. и принявшее радикальные формы после введения российских войск в Сирию осенью 2015 г. В конце 2016 - начале 2017 г., в связи с президентскими выборами в США, российский вопрос стал центральным в западных СМИ.

Следует также обратить внимание на ужесточение санкций в отношении российских медиа на Западе. Показательным является инцидент с телеканалом «Russia Today» в октябре 2016 г., когда все счета телеканала были заблокированы в Великобритании. Давлению подверглось также информационное агентство «Спутник». 
Стратегической целью этих и других подобных акций являлась изоляция России на глобальном медиапространстве, создание негативного образа нашего государства на мировом информационном поле.

Эта задача оказалась невыполнима в том числе и благодаря стратегическим союзникам России, не включившим свои голоса в хор идеологических противников нашего государства.

Россия внимательно относится к проблеме стратегического союзничества в информационной сфере; усиление внимания к этой теме можно проследить в развитии концепции национальной безопасности РФ. Сравнивая стратегии национальной безопасности РФ № 537 от 12 мая 2009 г. [8] и № 683 от 31 декабря 2015 г. [9] на предмет включения в эти документы вопросов информационной политики, можно с уверенностью отметить, что Россия намерена наращивать свой медийный потенциал, привлекая значительные интеллектуальные, финансовые и технологические ресурсы к развитию национального информационного сектора. Если в стратегии 2009 г. вопросы информационной безопасности оставались на втором плане, то в концепции 2015 г. они занимают одно из ключевых мест.

В концепции национальной безопасности 2015 г. особо отмечается стратегическая необходимость развития высокотехнологичных инструментов информационного сектора и подчеркивается важность предотвращения угроз, которые могут повлечь за собой сбой в функционировании информационных и телекоммуникационных систем критически важных объектов социальноэкономической инфраструктуры [9]. Внимание уделяется не только техническим, но и содержательным аспектам информационной борьбы. В документе отмечается, что страны Запада применяют - при помощи информационнокоммуникационных технологий - методы манипулирования общественным сознанием и фальсификации исторических фактов для достижения своих стратегических целей. Выявляются информационные угрозы, которые могут привести к дестабилизации ситуации в будущем.

Детальное рассмотрение вопросов информационной политики помогает укрепить уровень защищенности общества от дестабилизирующего информационного воздействия со стороны иностранных специализированных структур и, в том числе, террористических организаций. В этой связи приоритетным направлением обеспечения национальной безопасности Российской Федерации является увеличение уровня информационно-технологической безопасности, а также повышение роли России на мировой арене.

При этом Россия предполагает действовать сугубо в рамках принципов международной безопасности, сверяя свою политику с политикой $\mathrm{OOH}$ в сфере информатизации и развития телекоммуникаций. Для реализации поставленных задач Российская Федерация планирует осуществлять свою 
информационную политику в тесном взаимодействии с Советом Безопасности ООН и специализированными группами по ИТ.

В официальном докладе Группы экспертов ООН по достижениям в сфере информатизации и телекоммуникаций в контексте международной безопасности (№ A/65/201) рассматриваются многие технологические проблемы. Специалистами из разных стран мира планируются разработка и внедрение солидарных технологий информационной безопасности, а также механизмов управления глобальными информационными сетями и системами передачи данных [4]. Участие в подобных проектах является стратегически значимым для России.

Таким образом, мы видим, что в последние годы российские медиасистемы претерпевают существенные изменения [7]. Растет влияние российских СМИ на мировом мидиапространстве. Среди основных угроз для Российской Федерации можно выделить применение информационнокоммуникационных технологий международными террористическими организациями и международной экономической преступностью. Кроме того, сохраняется возможность использования информационно-коммуникационных технологий геополитическими противниками России в качестве инструмента для пропаганды антироссийских идей. Медийные технологии могут нанести существенный вред и внутренней стабильности общества. В этой связи Российская Федерация в кооперации со своими стратегическими союзниками стремится обеспечить коллективную информационную безопасность и усилить свою роль на международной арене.

\section{Библиография}

1. Виноградов А.В. Диалоговый формат БРИКС и его роль в становлении многополярного мира // Сравнительная политика. 2014. № 1 (14). С. 47-52.

2. Декларация VII саммита стран БРИКС в Уфе // http://brics2015.ru/documents/ (Дата обращения: 30.09.2016.)

3. Декларация стран БРИКС на Гоа // http://thailand.mid.ru/key-issues/1792-deklaratsiyagoа (Дата обращения: 17.10.2016.)

4. Доклад Группы правительственных экспертов ООН по достижениям в сфере информатизации и телекоммуникаций в контексте международной безопасности № A/65/201 // https:/unoda-web.s3-accelerate.amazonaws.com/wp-content/uploads/assets/HomePage/ODAPublications/DisarmamentStudySeries/PDF/DSS_33_Russian.pdf (Дата обращения: 17.01.2017.)

5. Ефременко Д.В. Смена вех: Россия и украинский кризис // Россия и современный мир. 2014. № 4 (В). С. 6-28.

6. Ильин И.В., Леонова О.Г., Алексеенко О.А. БРИКС как общий знаменатель стратегических приоритетов // Международная жизнь. 2016. № 8. С. 115-130.

7. Медиасистема России. М.: Аспект Пресс, 2015. 384 с.

8. Стратегия национальной безопасности РФ от 12 мая 2009 г. № 537 // https:// rg.ru/2009/05/19/strategia-dok.html (Дата обращения: 20.09.2016.) 
9. Стратегия национальной безопасности РФ от 31 декабря 2015 г. № 683 // https:// rg.ru/2015/12/31/nac-bezopasnost-site-dok.html (Дата обращения: 20.09.2016.)

10. Шестова Т.Л. Global Media и современный политический процесс // Вестник Московского университета. Сер. 27. Глобалистика и геополитика. 2016. № 3. С. 64-70.

\section{References}

Deklaracija stran BRIKS na Goa // http://thailand.mid.ru/key-issues/1792-deklaratsiya-goa (Data obrashhenija: 17.10.2016.)

Deklaracija VII sammita stran BRIKS v Ufe // http://brics2015.ru/documents/ (Data obrashhenija: 30.09 .2016$.

Doklad Gruppy pravitel'stvennyh jekspertov OON po dostizhenijam v sfere informatizacii i telekommunikacij v kontekste mezhdunarodnoj bezopasnosti № A/65/201 // https://unoda-web.s3accelerate.amazonaws.com/wp-content/uploads/assets/HomePage/ODAPubli-cations/Disarmament StudySeries/PDF/DSS_33_Russian.pdf(Data obrashhenija: 17.01.2017.)

Efremenko D.V. Smena veh: Rossija i ukrainskij krizis // Rossija i sovremennyj mir. 2014. N 4 (V). P. 6-28.

Il'in I.V., Leonova O.G., Alekseenko O.A. BRIKS kak obshhij znamenatel' strategicheskih prioritetov // Mezhdunarodnaja zhizn'. 2016. N 8. P. 115-130.

Mediasistema Rossii. Moscow: Aspekt Press, 2015. 384 p.

Shestova T.L. Global Media i sovremennyj politicheskij process // Vestnik Moskovskogo universiteta. Ser. 27. Globalistika i geopolitika. 2016. N 3. P. 64-70.

Strategija nacional'noj bezopasnosti RF ot 12 maja 2009 g. N 537 // https://rg.ru/ 2009/05/19/strategia-dok.html (Data obrashhenija: 20.09.2016.)

Strategija nacional'noj bezopasnosti RF ot 31 dekabrja 2015 g. N 683 // https://rg.ru/ 2015/12/31/nac-bezopasnost-site-dok.html (Data obrashhenija: 20.09.2016.)

Vinogradov A.V. Dialogovyj format BRIKS i ego rol' v stanovlenii mnogopoljarnogo mira // Sravnitel'naja politika. 2014. N 1 (14). P. 47-52. 